(107s.) ; to libraries, research laboratories, Government departments and industrial organizations, 30 dollars (214s.). New York and London: Pergamon Press, 1958). The first issue contains a number of articles on various aspects of radio and line telegraph and telephone matters. It also includes a brief review of the characteristics of U.S.S.R. State television standard for black-and-white television broadcasting on a 625 -line system.

The other two journals appear to be longer established. Radio Engineering and Electronics (2, No. 2, 1957. English edition. Pp. 1-183. Approximately 2,500 pages per annum. Annual subscriptions : to individuals, 22.50 dollars ( $160 \mathrm{~s}$.) ; to libraries, research laboratories, Government departments and industrial organizations, 45 dollars (320s.). New York and London: Pergamon Press, 1958) contains fourteen articles related to various subjects in electronics, including wave-guides, dielectrics and cathode-ray tubes. A brief article on the life and work of Heinrich Hertz, in relation to the centenary of his birth (February 22, 1857), is also included. Radio Engineering (12, No. 8, 1957. First English issue. Pp. 1-112. Approximately 2,500 pages per annum. Annual subscriptions: to individuals, 22.50 dollars (160s.); to libraries, research laboratories, Government departments and industrial organizations, 45 dollars (320s.). New York and London: Pergamon Press, 1958) is devoted to technical and theoretical aspects of the subject of its title, and is the official publication of the A. S. Popov Technical Society of Radio Engineering and Telecommunications.

\section{Coryndon Memorial Museum, Nairobi}

IT is pleasing to note that the annual report for 1957 of the Coryndon Memorial Museum at Nairobi makes no reference to any restrictions on its work by Mau Mau activities (pp. $28+1$ plate. 1958. Nairobi: Museums Trustees of Kenya and the Coryndon Memorial Museum). Instead, the whole energy of the staff has been turned to constructive measures, and several now exhibits have been prepared. The Bongo habitat group has been enlarged and new groups depicting Abbot's Duiker and Klip. springer installed. Exhibits dealing with the bats of East Africa, melanism and albinism proved popular. Additional marine and freshwater fish were shown in the aquaria, the most outstanding being a young shark and several species of dragon fish. In the Gandhi Hall the mineral and rock exhibits were augmented, many new geological maps were displayed and a new exhibit dealing with recent discoveries at Olduvai Gorge was placed on view. Stamps and postal literature have now been included in the collections.

\section{Forestry in Ulster}

Av illustrated pamphlet, "Forestry in Northern Treland" (pp. 20. Belfast : Ministry of Agriculture, 1958), which includes a map of these forests, issued by the Ministry of Agriculture, Northern Ireland, appears to be admirably designed to serve its purpose as a piece of public relations policy. It sets forth clearly and concisely the origin and development of the State forests, the purpose they serve and the policy pursued in their management. At the same time, it indicates their need of public understanding and support, as well as the nature of that support and the contribution to public amenity and enjoyment which the forest parks now offer. A regulation made under the Forestry Act (Northern Ireland), 1953, declared Tollymore Park, near Newcastle, County Down, open to the public as a forest park, and the Park, which covers about 1,200 acres, was officially opened on June 2, 1955.

\section{Careers in the Plastics Industry}

UNDER the title "Careers in Plastics" (pp. 20. London: The Plastics Institute, London, 1958), the Plastics Institute has issued, for the guidance of senior scholars and those responsible for advising them on the choice of a career, a pamphlet setting forth the opportunities presented by the rapidly growing plastics industry, particularly for those with technical qualifications or scientific training. Besides a summary of the technical appointments available, the pamphlet includes information on the constitution of the industry, and particulars of how to enter it, and the technological, professional and academic qualifications desirable (with a chart indicating the various routes by which they may be obtained) and details of teaching centres where approved courses for the qualifications of the Plastics Institute can be pursued. Some indication is given of salaries and prospects, and there is a short appendix on the pupil apprenticeship scheme for the industry, which shows incidentally how well placed a professional body is to press for the adjustment of apprenticeship conditions to meet modern needs.

\section{The National Institute for Research in Dairying}

RESEARCH workers in many branches of science, practical farmers and agricultural advisory officers will all find something of interest and importance in the annual report of the National Institute for Research in Dairying for 1957 (pp. 160. Shinfield: National Institute for Research in Dairying, University of Reading, 1958. 4s.). It is largely devoted to a concise account of the research work done in each of the various departments and sections of which the Institute is composed, while for those who do not require to have so much detail a brief outline is given of many of the recent research findings. The subjects dealt with in the brief outline range from such immediately practical problems as labour-saving devices in feeding lactating sows and grazing management of lactating cows, to basic work such as that on the utilization of amino-acids by the isolated perfused bovine udder and the deoxyribonucleic acid content and histology of the mammary gland. Mention of work done by the Statistical Section on the derivation of general orthogonal polynomials helps to illustrate the breadth of the Institute's programme of work, and in this atomic age perhaps it is not surprising to find that the problem of salvaging milk which has been contaminated with radiostrontium has already been studied. The report gives a detailed list of $15 \mathrm{I}$ papers most of which were published in 1957 .

\section{The Marshall Pulse Height Analyser HS 100}

THE Marshall pulse height analyser has been developed at the Airport Works of Marshall of Cambridge under licence from the National Research Development Corporation, with the object of producing a first-class British instrument exhibiting all the characteristics of existing analysers at a fraction of the cost but retaining their accuracy and achieving the utmost reliability. This is effected by the use of the Hutchinson-Scarrott principle, using computer techniques for the storage of information performed in serial manner using two torsional acoustic delay lines. This system is inherently simpler in construc- 